Plant Tissue Cult. \& Biotech. 18(1): 1-6, 2008 (June)

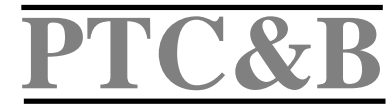

\title{
In vitro Propagation of Mentha viridis L. from Nodal and Shoot tip Explants
}

\section{H. David Raja and D.I. Arockiasamy*}

Center for Natural Resources Studies, Department of Botany, St. Joseph's College, Trichy-2. India

Key words: Micropropagation, Mentha viridis, Node, Shoot tip, Multiple shoots

\begin{abstract}
A simple micropropagation method from nodal and shoot tip explants is reported here for Mentha viridis, an economically important medicinal plant. High frequency of microshoots was obtained from these two explants on MS supplemented with various concentrations of BAP (1.0 - $4.0 \mathrm{mg} / \mathrm{l})$ and $\mathrm{Kn}(1.0$ $4.0 \mathrm{mg} / \mathrm{l})$. Maximum number of shoots was obtained from nodal explants in the medium containing $3.0 \mathrm{mg} / 1 \mathrm{BAP}$. The root induction was carried out by using IBA and IAA (0.5 - $2.0 \mathrm{mg} / \mathrm{l})$. Among these, high frequency of root proliferation was achieved in the medium containing $1.5 \mathrm{mg} / 1$ of IBA. The rooted plantlets were hardened and transferred to the field. The survival rate was $90-95 \%$ after 25 days.
\end{abstract}

\section{Introduction}

The growing interest in the commercialization of plant based medicines has lead to over exploitation of the plants. The sad part of this situation is that medicinal plants related trade specially in India depends on the natural populations which is not sustainable and will certainly lead to species extinction. Hence, we need to develop the concept of medicinal crop and employ the modern tools to meet our domestic and export needs. In this condition, plant tissue culture is considered as promising technology to get over this hurdle and play a major role in the mass multiplication, germplasm production, conservation, secondary metabolite production and sustainable use of medicinal plants. Recognition of the 'Medicinal Crop' concept is the only way to compete the global medicinal plant market both quantitatively and qualitatively. Tissue culture in turn is the only way to sustain the large scale farming of medicinal plants, as this is the only technique to produce plants of high and uniform quality in large quantity from any part of the plant in any season (Hassan and Roy 2005). This technique provides a rapid reliable system for production of large number of genetically uniform and even disease free plantlets.

*Department of Plant Biology and Biotechnology, St. Joseph's College, Trichy-2, India. E-mail: darockia05@rediffmail.com 
The Labiates (Lamiaceae) form one of the largest and most highly evolved plant families with world-wide distribution. The family contains around 200 genera and between 2000 and 5000 species of aromatic and medicinal herbs and low shrubs. The genus Mentha (Lamiaceae) is composed of 19 geographically widespread species and 13 named hybrids.

Essential oil from Mentha viridis is considered industrially important. India is one of the largest mint oil producers. It has exported about 8500 tons of oil in 2002 - 2003. Commercially, the most important mint species are peppermint ( $M$. piperita), spearmint (M. spicata/M. viridis), and corn mint (M. canadensis). Green leaves of the plant are used for making chutney and for flavoring culinary preparations, vinegar, jellies and iced drinks. The herb is considered stimulant, carminative and antispasmodic. A soothing tea is brewed from the leaves and an alcoholic beverage (mint julep) is prepared from them and used as an antidote for poison. A sweetened infusion of the herb is given as a remedy for infantile troubles, vomiting in pregnancy and hysteria. The leaves are used in fevers and bronchitis. Spearmint oil is used for flavoring, chewing gums, tooth paste, confectionery and pharmaceutical preparations. Present study is aimed at developing simple, reliable and reproducible method to produce saplings of Mentha viridis L. in mass both as a means of commercial use and conservation.

\section{Materials and Methods}

Nodal and shoot tip segments from healthy plants of Mentha viridis L. were used in the present study. The explants were collected, washed thoroughly under running tap water for $15 \mathrm{~min}$. These were treated with $5 \%$ teepol $(\mathrm{w} / \mathrm{v})$ and $0.1 \%$ $(\mathrm{w} / \mathrm{v})$ bavistin for 5 minutes and again washed thoroughly in running tap water. After that, nodal and shoot tip segments were surface sterilized with $0.1 \% \mathrm{HgCl}_{2}$ for 4 minutes, followed by washings with sterile double distilled water inside the laminar airflow chamber to remove traces of $\mathrm{HgCl}_{2}$. The surface sterilized shoots were excised to obtain node and shoot tip explants. Explants were cultured individually on MS containing different concentrations $(1.0-4.0 \mathrm{mg} / \mathrm{l})$ of BAP and $\mathrm{Kn}$. After regeneration and sufficient elongation, the microshoots were carefully excised and rooted on MS with IBA and IAA separately. Both proliferation and rooting media contained 3\% sucrose and gelled with $0.8 \%$ agar (Hi-Media, India). The $\mathrm{pH}$ was adjusted to $5.6 \pm 0.1$. All the cultures were maintained in a growth room with a $16 \mathrm{~h}$ photoperiod (cool, white fluorescent light - $30 \mu \mathrm{mol} \mathrm{m} / \mathrm{s}$ ) and the temperature was maintained at $25 \pm 2^{\circ} \mathrm{C}$, with 50 -

$80 \%$ relative humidity. Each treatment consisted of ten replicates and experiment repeated twice. 


\section{Results and Discussion}

Nodal and shoot tip explants from field grown plants of Mentha viridis were inoculated on MS supplemented with BAP and $\mathrm{Kn}$ at different concentrations $(1.0,2.0,3.0$ and $4.0 \mathrm{mg} / \mathrm{l})$ for production of multiple shoots. The proliferation efficiency of nodal explants from healthy plants was significantly higher than that of shoot tip explants when evaluated five to six weeks. As a supplement, 3.0 $\mathrm{mg} / 1$ BAP resulted in maximum proliferation was noted in $95 \%$ cultured explants (Fig. $1 \mathrm{a}, \mathrm{b})$. The nodal explants produced the highest number $(42.00 \pm$ 4.42) shoots per culture with a mean length of $9.45 \pm 4.13 \mathrm{~cm}$ (Table 1, Fig. 1b). On the similar medium, shoot tip explants, produced shoots in $75 \%$ of the cultures (Fig. 1c,d). The shoot tip explants produced maximum number of

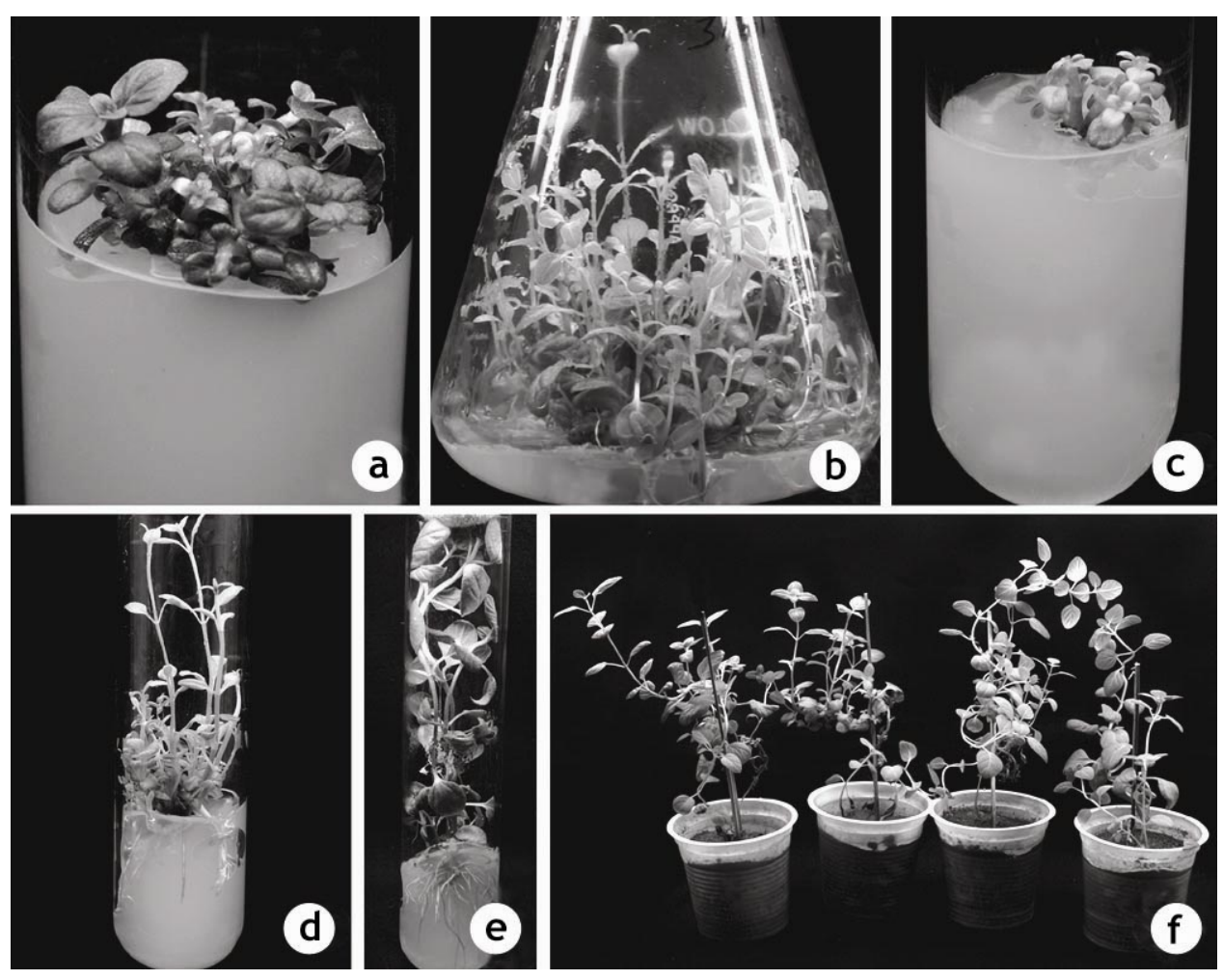

Fig. 1. (a) Microshoots initiation from shoot tip explant. (b) High frequency of multiple shoot formation from shoot tip explant. (c) Microshoots initiation from nodal-explant. (d) High frequency multiple shoots production from nodal explant. (e) Rooting of elongated shoot. (f) Hardened plantlets.

(37.35 \pm 5.82$)$ shoots per culture on the same medium, average length of the in vitro shoots being $7.10 \pm 4.36 \mathrm{~cm}$ (Table 1, Fig. 1d). When the explants were cultured on Kn based medium only 20 - $65 \%$ of them responded to proliferation. In this treatment the highest number of shoots per explant and average shoot 
lengths were $34.00 \pm 5.01$ and $6.70 \pm 4.28 \mathrm{~cm}$ for nodal explants, $32.05 \pm 4.75$ and $5.80 \pm 3.81$ (Table 1) for shoot tip explants, respectively.

Table 1. Effect of different cytokinins on shoots induction from nodal and shoot tip explants of Mentha viridis.

\begin{tabular}{|c|c|c|c|c|c|c|}
\hline \multicolumn{4}{|c|}{ Nodal explant } & \multicolumn{3}{|c|}{ Shoot tip explant } \\
\hline $\begin{array}{l}\text { PGR } \\
(\mathrm{mg} / \mathrm{l})\end{array}$ & $\begin{array}{l}\% \text { of } \\
\text { response }\end{array}$ & $\begin{array}{l}\text { No. of shoots/ } \\
\text { culture } \\
(\text { Mean } \pm \text { Sd) }\end{array}$ & $\begin{array}{l}\text { Av. length of } \\
\text { shoots }(\mathrm{cm}) \\
(\text { Mean } \pm \text { Sd) }\end{array}$ & $\begin{array}{l}\% \text { of } \\
\text { response }\end{array}$ & $\begin{array}{c}\text { No. of shoots/ } \\
\text { culture } \\
\text { (Mean } \pm \text { Sd) }\end{array}$ & $\begin{array}{l}\text { Av. length of } \\
\text { shoots }(\mathrm{cm}) \\
(\text { Mean } \pm \text { Sd) }\end{array}$ \\
\hline \multicolumn{7}{|l|}{ BAP } \\
\hline 1.0 & 25 & $13.85 \pm 8.10$ & $3.20 \pm 0.63$ & 30 & $15.50 \pm 9.37$ & $2.90 \pm 0.99$ \\
\hline 2.0 & 35 & $26.40 \pm 9.65$ & $8.00 \pm 4.27$ & 55 & $26.80 \pm 6.81$ & $6.70 \pm 4.28$ \\
\hline 3.0 & 95 & $42.00 \pm 4.42$ & $9.45 \pm 4.13$ & 80 & $37.35 \pm 5.82$ & $7.10 \pm 4.36$ \\
\hline 4.0 & 70 & $19.35 \pm 12.41$ & $3.95 \pm 3.89$ & 50 & $27.35 \pm 6.58$ & $2.85 \pm 3.82$ \\
\hline \multicolumn{7}{|l|}{ Kn } \\
\hline 1.0 & 20 & $15.15 \pm 8.44$ & $2.80 \pm 0.91$ & 25 & $28.65 \pm 6.08$ & $2.00 \pm 0.81$ \\
\hline 2.0 & 30 & $27.65 \pm 7.34$ & $5.60 \pm 4.05$ & 45 & $28.75 \pm 4.96$ & $5.30 \pm 5.90$ \\
\hline 3.0 & 75 & $34.00 \pm 5.01$ & $6.70 \pm 4.28$ & 65 & $32.05 \pm 4.75$ & $5.80 \pm 3.81$ \\
\hline 4.0 & 50 & $13.65 \pm 9.38$ & $2.50 \pm 2.68$ & 40 & $20.10 \pm 8.38$ & $1.45 \pm 2.03$ \\
\hline
\end{tabular}

Twenty explants were used for each treatment and data (Mean $\pm \mathrm{Sd}$ ) recorded five - six weeks after culture.

Comparative analysis of the results on the various cytokinins used indicated that proliferation of shoots was more effective in most of the BAP concentrations. The percentage of explants showing proliferation and the number of shoots per culture increased gradually with an increase of cytokinins concentration from 1.0 to $3.0 \mathrm{mg} / \mathrm{l}$. When the concentration of cytokinins increased to above $3 \mathrm{mg} / \mathrm{l}$, shoot regeneration frequency decreased and vitrification occurred. At the highest level of cytokinins $(4.0 \mathrm{~g} / \mathrm{l})$, the explants produced minimum number of shoots. Similar results were also reported in Prosalia corylifolia (Jebakumar et al. 2000) and Terminalia arjuna Roxb. (Varghese et al. 2003). The results of this experiment also indicate that $3.0 \mathrm{mg} / 1 \mathrm{BAP}$ was more suitable than $3.0 \mathrm{mg} / 1 \mathrm{Kn}$ for shoot proliferation (Table 1). No earlier report is available in Mentha viridis and not much work has been carried out in other species of Mentha. Shasany et al. (1998) have achieved regeneration of shoot from nodal explants of Mentha arvensis with MS supplemented with $5 \mathrm{mg} / 1$ BAP (Shasany et al. 1998). Van Eck and Kitto (1992) have experimented the regeneration from leaf discs of peppermint and orange mint. They have reported that supplementing $44.4 \mathrm{mg} / 1 \mathrm{BAP}$ and 250 $\mathrm{ml} / 1 \mathrm{CW}$ could produce better results. Similar results were also reported in Datura metel (Muthukumar et al. 2004), Centella asiatica (Shashikala et al. 2005), and Spilanthes paniculata (Mahendra et al. 2006). 
Root induction was carried out in the in vitro regenerated well elongated shoots by culturing them on MS with $0.5-2.0 \mathrm{mg} / 1$ either IBA or IAA. In the present study, IBA (1.5 mg/l) was found to be most effective for rooting (Fig. 1e). Maximum number of roots $(11.99 \pm 0.99)$ were produced in $1.5 \mathrm{mg} / 1 \mathrm{IBA}$ and mean root length was found to be $7.60 \pm 1.07 \mathrm{~cm}$ (Table 2). Similar results were also reported in Ocimum amaricannum (Pathnaik and Chand 1996), Hybanthus enneaspermus (Natarajan et al. 1999), Tylophora asthmatica (Usha et al. 2002).

Table 2. Effect of different concentrations of IBA and IAA on root induction from in vitro grown microshoots of Mentha viridis.

\begin{tabular}{ccccc}
\hline $\begin{array}{c}\text { Conc. of auxins } \\
(\mathrm{mg} / \mathrm{l})\end{array}$ & $\begin{array}{c}\text { \% of } \\
\text { response }\end{array}$ & $\begin{array}{c}\text { No. of } \\
\text { roots/explant } \\
(\text { Mean } \pm \text { Sd })\end{array}$ & $\begin{array}{c}\text { Av. length of } \\
\text { roots }(\mathrm{cm}) \\
(\text { Mean } \pm \text { Sd) }\end{array}$ & $\begin{array}{c}\text { Days to } \\
\text { emergence of } \\
\text { roots }\end{array}$ \\
\hline IBA & 65 & $4.30 \pm 1.61$ & $2.80 \pm 0.85$ & $15-18$ \\
0.5 & 85 & $8.20 \pm 2.40$ & $4.01 \pm 1.30$ & $13-17$ \\
1.0 & $\mathbf{1 0 0}$ & $\mathbf{1 1 . 9 9} \pm \mathbf{0 . 9 9}$ & $\mathbf{7 . 6 0} \pm \mathbf{1 . 0 7}$ & $\mathbf{1 2 - 1 5}$ \\
$\mathbf{1 . 5}$ & 75 & $6.13 \pm 2.10$ & $3.60 \pm 1.30$ & $13-17$ \\
2.0 & 50 & $2.40 \pm 1.90$ & $1.73 \pm 0.88$ & $14-20$ \\
IAA & 65 & $3.60 \pm 0.45$ & $2.80 \pm 1.10$ & $14-18$ \\
0.5 & 60 & $3.30 \pm 1.70$ & $2.10 \pm 0.47$ & $15-21$ \\
1.0 & & & & \\
1.5 & & & & \\
\hline
\end{tabular}

Twenty microshoots were used for each treatment and data (Mean $\pm \mathrm{Sd}$ ) collected after four - five weeks of culture.

Rooted plantlets were carefully removed from the medium and treated with $10 \%$ bavistin for protecting the root system from fungal infection. After the bavistin treatment, roots were washed with distilled water six to eight times and transferred to plastic cups containing $1: 1: 1$ red soil, vermicompost and vermiculite (Fig. 1f). In the first week of transplantation plantlets were covered with a polythene tent for providing the condition of high humidity and sufficient light. The polythene cover was removed periodically and progressively whenever leaves appeared water soaked. When new leaves developed in the micropropagated plants inside the polythene tent in two - three weeks the plants were transferred to large earthen pots or poly bags filled with soil and organic manure. Through this process of acclimatization, regenerated plantlets were established under ex vitro conditions. About $90-95 \%$ of the regenerated plantlets could tolerate and survive under ex vitro environment or field conditions. 


\section{References}

Hassan AKMS and Roy SK (2005). Micropropagation of Gloriosa superba L. through high frequency shoot proliferation. Plant Tissue Cult. 15(1): 67-74.

Jebakumar M and Jayabalan M (2000). An efficient method for regeneration of plantlets from nodal explants of Prosalea corydifolia Linn. Plant Cell Biotec. Mol. Biol. 1(1\&2): 37-40.

Mahendra G, Lavanya Devi K and Narmatha Bai V (2006). Micropropagation of Spilanthes paniculata Wall ex. DC. Plant Cell. Biotech. and Mol. Biol. 7(1\&2): 85-88.

Muthukumar B, Arockiasamy D and Natarajan E (2004). Direct organogenesis in Datura metal L. from in vivo nodal explants. Ind. J. Biotech. 3: 449-451.

Natarajan E, Arockiasamy D and John Britto S (1999). Regeneration of plantlets from the callus of stem explants of Hybabanthes enneaspermus (L.) F. Muell, Plant Tissue Cult. 9: 167-172.

Pathnaik SK and Chand PK (1996). In vitro propagation of the medicinal herbs Ocimum americanum. Syn. Ocimum sims Hoary Basil and Ocimum sanctum (Holly Basil). Plant Cell Report.15: 846-860.

Shasany AK, Khanujia S, Dhawan S, Yadav U, Sharma S and Kumar S (1998). High regenerative nature of Mentha arvensis internodes. J. Biosciences 23: 641-646.

Shashikala CM, Shashidhara S and Raja Shekharan PE (2005). In vitro regeneration of Centella asiatica L. Plant Cell. Biotech. and Mol. Biol. 6(1\&2): 53-56.

Usha Mukundan, Latha Sivaram and Anil Kumar (2002). Micropropagation of Tylophora ashumatica and Uararia picta. Plant Cell. Biotech. and Mol. Biol. 3(1\&2): 73-76.

Van Eck JM and Kitto SL (1992). Regeneration of peppermint and orange mint from leaf disks. Plant Cell, Tissue and Organ Cult. 30(1): 41-49.

Varghese T, Rema Shree AB, Naheesa E, Neelakandan N and Nandakumar S (2003). In vitro propagation of Terminalia arjuna Roxb. multipurpose tree. Plant cell Biotech. Mol. Biol. 4 (1\&2): 95-98. 